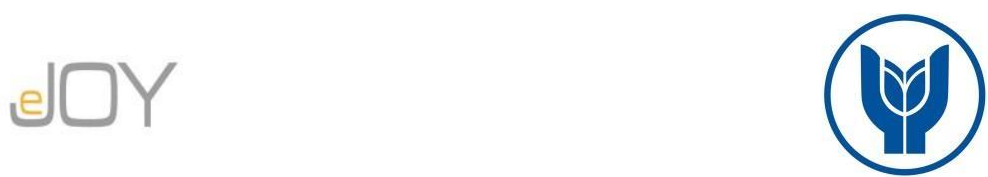

Felek, Ş., Yayla, N., Çeviş, İ. / Journal of Yasar University, 2021, 16/63, 1164-1184

\title{
Türkiye’de Finansal Gelişme Ve Finansal Kırılganlık İlişkisi Üzerine Bir Analiz: 2007-2019
}

\section{An Analysis on the Relationship Between Financial Development and Financial Fragility in Turkey: 2007-2019}

\author{
Şencan FELEK, Pamukkale Üniversitesi, Türkiye, sencanfelek@gmail.com \\ Orcid No: 0000-0002-4672-6259 \\ Nihal YAYLA, Pamukkale Üniversitesi Türkiye, nyayla@pau.edu.tr \\ Orcid No: 0000-0002-0647-5088 \\ İsmail ÇEVİŞ, Pamukkale Üniversitesi, Türkiye, icevis@pau.edu.tr \\ Orcid No: 0000-0001-6246-8707
}

\begin{abstract}
Öz:70'li yıllardan itibaren dünyada yaygınlaşan finansal liberalizasyon süreci bir taraftan ekonomilerin finansal gelişmişlik düzeyine olumlu katkılar sağlarken diğer taraftan da finansal kırılganlık düzeylerinin artmasına zemin hazırlamıştır. Türkiye de 1980 sonrasında finansal liberalleşme akımına ayak uydurmaya başlamış ve 1989'da tam liberalizasyona geçiş yapmıştır. 1990 sonrasında ardarda yaşanan krizler ise liberalizasyon sürecinin Türk finans sistemine yönelik dersleri niteliğinde olmuştur. 2001 krizinden sonra bu dersleri iyi değerlendiren Türkiye, 2008 küresel krizinden en az hasarla çıkan ekonomiler arasında olmayı başarmıştır. 2007-2019 dönemi için finansal gelişme endeksi ve finansal kırllganlık endeksinin Temel Bileşenler Analizi yöntemi kullanılarak hesaplandığ çalışmada bu iki endeks arasındaki ilişkiler ARDL (sınır testi) yaklaşımı ile incelenmiştir. Elde edilen bulgular Türkiye'de finansal gelişmişlik artarken finansal kırllganlığın giderek azaldı̆̆ını göstermektedir. Bu durum, finansal kesimde gerçekleştirilen yasal ve kurumsal düzenlemelerin önemine vurgu yapacak niteliktedir.
\end{abstract}

Anahtar Kelimeler: Finansal Gelişme, Finansal Kirllganlık, ARDL

\section{JEL Sinıflandirmast: G01, G10, D53, O16}

Abstract: The process of financial liberalization, which has become widespread in the world since the 70s, has provided a positive contribution to the level of financial development of economies, as well as a basis for increasing the level of financial fragility. Turkey also joined the financial liberalization movement after 1980 and switched to full liberalization in 1989. Successive crises after 1990 were the lessons of the liberalization process for the Turkish financial system. Having evaluated these lessons well after the 2001 crisis, Turkey has been one of the economies that emerged from the 2008 global crisis with the least damage. In this study, in which the financial development Index and the financial fragility index were calculated for the period 2007-2019 using the Principal Component Analysis technique, the relations between these two indices were examined using the ARDL (boundary test) approach. The findings show that while the level of financial development is increasing in Turkey, financial fragility is gradually decreasing. This situation emphasizes the importance of legal and institutional regulations appeared in the financial sector.

Keywords: Financial Development, Financial Fragility, ARDL

JEL Classification: G01, G10, D53, O16

\section{Giriş}

Küreselleşmenin de etkisiyle finansal sistem, ekonomilerin performanslarının önemli bir belirleyicisi durumuna gelmiştir. İyi işleyen bir finansal sistemin tasarruf oranlarını artıracağı, kaynakların etkin dağılımını sağlayacağı, fiziki ve beşeri sermaye birikimini hızlandıracağı, teknolojik gelişmeleri teşvik edeceği, yoksulluğu azaltacağı, hayat standardını artıracağı sıça belirtilen hususlardır. Buna karşılık kötü işleyen bir finansal sistemin ekonomik büyümeyi 
sekteye uğratarak ekonomilerin istikrarsızlaşmasına neden olacağına da vurgu yapılmaktadır. Genel olarak finansal sistemdeki gelişmelerin uzun dönemde ekonomik büyümeyi ve kalkınmayı olumlu etkilediği kabul edilmekle beraber, herhangi bir makroekonomik istikrarsızlığın bu olumlu etkileri tersine çevirme gibi bir ihtimali de her zaman bulunmaktadır.

Finansal gelişme ve ekonomik büyüme arasındaki ilişkiye yönelik tartışmalar oldukça eskiye dayanmaktadır. Schumpeter (1911), bankacılık sistemi ve finansal aracıların ekonomik büyümedeki önemine vurgu yaparak, finansal piyasaların yenilikleri ve üretken yatırımları finanse etmek suretiyle sermaye birikimini ve gelecekteki büyümeyi teşvik edeceğini ifade etmektedir. Robinson (1952) ise buna ek olarak reel ekonomi büyüdükçe, finansal hizmetlere olan talebi karşılamak için daha fazla finansal hizmet ve kurumun ortaya çıkacağını öne sürmektedir. Yani, finansal gelişme ekonomik büyümeyi takip etmektedir.

Son elli yıldır finansal liberalizasyonun, küreselleşen ekonomilerde hem finansal gelişmenin hem de ekonomik büyümenin en belirleyici unsuru olduğu kabul edilmektedir. $\mathrm{Bu}$ konuda önderlik yapan Mckinnon (1973) ve Shaw (1973) hipotezine göre, finansal liberalleşme politikalarından kaynaklanan yüksek faiz oranları, hanehalklarını tasarruflarını artırmaya teşvik etmektedir. Finansal aracılık sürecini teşvik eden bu politikalar diğer taraftan da özel sektörün kredili fon bulma imkanını hızlandırmaktadır. Bu durum yatırımların düzeyini artırarak sermayenin verimli alanlara aktarılmasına ve dolayısıyla da ekonomik büyümeye yol açmaktadır.

1970'lerin başından itibaren ortaya çıkan ve McKinnon-Shaw hipotezine dayandırılan finansal liberalleşme programları dalgası yalnızca gelişmiş ülkeleri değil gelişmekte olan ülkeleri de hızla etkisi altına almıştır. Gelişmekte olan ülkelerin ekonomilerini yeniden yapılandırmaları ve hızlı bir büyüme sağlayabilmeleri için tamamen serbestleşmiş ve pazar odaklı sistemlere geçmeleri gerektiği savunulmaya başlanmıştır. Bu dönemde uygulanan politikalar özellikle faiz oranlarının serbestleştirilmesini ve verimli projelere kredi tahsis edilmesi yoluyla finansal sistemin verimliliğinin artırılmasını amaçlamıştır. İyi işleyen bir finansal sistemde tasarruflar en verimli yatırım projelerine tahsis edilecek, risklerin çeşitlendirilmesi sağlanacak, ticaret akışı kolaylaşacak ve ekonomik büyüme hızlanacaktır.

Yaşanan son küresel finansal kriz tamamen serbestleştirilmiş ve denetimden uzak bir finansal sistemin ekonomik büyümeyi nasıl etkileyeceğini göstermiştir. Dolayısıyla düzenleme ve denetimden uzak bir finansal sistemin, finansal krize yol açma olasılığının yüksek olduğu ve finansal kırılganlığa neden olduğu düşüncesi de yaygınlaşmaya başlamıştır. Literatürdeki tartışmalar 1şığında, finansal liberalleşme politikalarının beklenen sonuçları elde etmede 
başarılı olup olmadığını anlamak için finansal gelişme ve finansal kırılganlık arasındaki ilişkilerin araştırılması büyük önem taşımaktadır.

$\mathrm{Bu}$ çerçevede ele alınan çalışmada, Türkiye'de finansal gelişme ve finansal kırılganlık ilişkisi incelenmektedir. Finansal liberalizasyon süreciyle birlikte finansal gelişme düzeyinin artmasının finansal kırılganlık üzerinde oluşturduğu etkinin hangi yönde olduğunun belirlenmesi ve ayrıca bu ilişkinin belirlenmesiyle Türk finans sistemindeki yasal ve kurumsal düzenlemelerin yeterlilik düzeyinin tespit edilmesi amaçlanmaktadır. Bu kapsamda çalışmanın ikinci bölümünde genel olarak finansal gelişme ve finansal kırılganlık ilişkisine değinilmiş ve bu konudaki literatüre yer verilmiştir. Türkiye'deki finansal liberalizasyon sürecine ve bu sürecin içinde yer alan krizlere üçüncü bölümde kısaca değinildikten sonra dördüncü bölümde, Türkiye için finansal gelişme ve kırılganlık endeksi hesaplanarak aralarındaki ilişkiye yönelik ekonometrik bir analiz gerçekleştirilmiştir. Son bölümde ise elde edilen bulgular yorumlanmış ve genel bir değerlendirme yapılmıştır.

\section{Finansal Gelişme ve Finansal Kırılganlık İlişsisi}

Finansal gelişmeyi dar anlamda finansal sistemin hem genişlik hem de yapısal açıdan değişimi olarak tanımlamak mümkündür. Başka bir ifadeyle finansal gelişme, bir ekonominin parasallaşma düzeyini ve finansal aracılık hizmetlerinin boyutunu gösteren bir ölçüt olarak da tanımlanabilir. Genel anlamda ise finansal gelişme, finansal piyasaların veya kurumların sermayeyi verimli yatırım alanlarına yönlendirerek piyasa başarısızlıklarını azaltmaları sonucunda ortaya çıkan bir durumdur. Finansal gelişme ve ekonomik faaliyetler arasındaki ilişkinin yönü konusunda literatürde çok farklı görüşler bulunmakla birlikte yatırımlar açısından bir finansal sistemin varlığı oldukça önemlidir ve ekonomi büyüdükçe finansal sistemin de daha fazla yatırıma finansman sağlayacak şekilde genişlemesi zorunlu olmaktadır.

1950'li ve 1960'l y yllarda devletin faiz oranı tavanı ve kredi kontrolleri gibi politikalar uygulayarak ve devlet bankaları kurarak finansal piyasalara müdahale etmesinin büyümeyi teşvik edeceği konusunda genel bir kanı bulunmaktaydı. Bu tür devlet müdahaleleri literatürde finansal baskı olarak da tanımlanmaktadır (Andersen ve Tarp 2003). Bu politikalar, 1970’lerin başında finansal sektörün liberalleşmesinin ekonomik büyümeyi artıracağını savunan McKinnon (1973) ve Shaw (1973) tarafından şiddetle eleştirilmiştir. McKinnon ve Shaw’a göre, faiz oranlarının düşük tutulması tasarrufları negatif yönde etkileyecek ve bu durum bankacılık sektörünün gelişimine zarar verecektir. Aynı şekilde kredi talebi aşırı genişleyecek ve bu durum bankaların kredileri verimli yatırım projelerine yönlendirmesini önleyerek, sermayenin etkin dağılımını engelleyecektir. 1970'lerden sonra ülkeler faiz ve kredi 
kontrollerini azaltarak, yerli ve yabancı bankalar için giriş engellerini kaldırıp ve sermaye hesaplarını liberalleştirerek finansal liberalizasyona geçiş yapmaya başladılar. Beklentiler, bankalar arası rekabetin artması ve bu durumun da finansal gelişmeyi artırması şeklindeydi. Çünkü bankalar yüksek faiz oranları ile daha yüksek oranda tasarruf çekmeye başlayacaklar ve böylece yatırımlar da giderek artacaktı. Aynı zamanda artan rekabet genel maliyetlerin azalmasını sağlarken diğer taraftan da bankacılık ve risk yönetiminin iyileşmesine katkıda bulunacaktı (Denizer, vd., 2007). Yabancı banka girişleri ise yeni bankacılık ve risk yönetimi tekniklerinin, yeni finansal araçların ve hizmetlerin yaygınlaşmasını sağlayacaktı (Claessens, vd. 2001). Sermaye hesabının liberalizasyonuyla birlikte yerli ve yabancı yatırımcılar için portföy çeşitlendirmesi imkanının artması ve yerel finans piyasalarının gelişiminin teşvik edilmesi de beklentiler arasındaydı (Chinn ve Ito 2006). Böylece küreselleșen dünya ekonomisinin elde edeceği kazançlardan mahrum olmaktan korkan gelişmekte olan ülkeler finansal liberalleşmeye post Washington döneminde (1990 sonrası) hız vermişlerdir (Gore 2000).

Ancak finansal liberalizasyondan beklenen bu pozitif etkiler oldukça tartışmalı bir konudur. Stiglitz (2000), finansal piyasaların serbestleștirilmesinin daha verimli kredi tahsisine yol açacağı düşüncesinin hatalı olduğunu savunmaktadır. Stiglitz’e göre bu düşünce, tam bilgi varsayımı altında doğru olmakla birlikte finansal piyasalar asimetrik bilgi ile karakterize edilmektedirler. Dolayısıyla bankaların faiz oranlarını serbestçe ayarlamasına izin vermek her zaman Pareto-optimum bir dengeye yol açmayacaktır. Benzer şekilde Boot (2000) da finansal liberalleşmenin bilgi asimetrilerini daha da kötüleştirebileceğini savunmaktadır. Banka rekabeti arttıkça ve faiz oranları düştükçe, borçlular bankalarıyla uzun vadeli ilişkilerini sona erdirebilirler. Borçluların diğer bankalara geçmesi sonucunda önceki bankanın borçlularıyla ilgili topladığı bilgiler artık değer taşımayacak ve bu da bilgi asimetrilerini daha da artıracaktır. Verimliliği düşük bankalar ise genel giderlerini azaltarak rekabet edemedikleri için bir kumar stratejisi benimseyebilirler, yani karlı kalmak için bilgi toplama ve izleme çabalarını azaltırlar (Hellmann, vd., 2000; Andersen ve Tarp 2003). Uzun vadede verimsiz bankaların yerini daha verimli bankalar alacak olsa da (Kaminsky ve Schmukler 2008), kısa vadede finansal liberalleşme verimlilik yerine istikrarsızlığa yol açabilir.

Bazı yazarlar ise finansal liberalleşme sonrasında sermaye girişlerinin genellikle spekülatif bir yapıya sahip olduğunu ve uzun vadeli yatırımlara yol açmadığını vurgulamaktadırlar (Rodrik 1998; Stiglitz 2000). Bu durum, ani sermaye çıkışlarına yol açabilir ve bunu potansiyel olarak bankacılık krizleri izleyebilir (Diamond ve Dybvig 1983; Demirgüç-Kunt ve Detragiache 1998; Rodrik 1998). 
Finansal liberalizasyonun olumlu yönlerine yapılan bu eleştiriler pratikte yaşanan ülke deneyimleri ile de ispatlanmıştır. Bazı ülkeler, ekonomik gerilemelerin eşlik ettiği derin finansal krizler yaşamıştır. 1980'lerin başında Arjantin ve Şili de, 1996'da Meksika'da, 19971999'da Güneydoğu Asya'da yaşanan krizler ve 2007-2008'deki küresel kriz bunun açık birer örnekleridir.

Finansal liberalizasyonun finansal gelişmeyi teşvik etmedeki etkinliği konusundaki ampirik çalışmalardan elde edilen bulgular da birbirinden oldukça farklıdır. Finansal liberalleşmenin finansal gelişme üzerindeki net etkisi olumlu görünmekle birlikte ele alınan ülkeler ve dönemler itibariyle farklılıklar bulunmaktadır. Bu farklılıkları dikkate alan son çalışmalar ise başarılı finansal liberalleşme politikalarının ön koşullarını belirlemeye yöneliktir. Örneğin Hermes ve Meesters (2015), finansal liberalleşmenin banka verimliliği üzerindeki etkisinin, bankacılık sisteminin düzenlenmesi ve denetlenmesinin kalitesine bağlı olduğunu ifade etmektedir. Sahay vd. (2015) tarafından yapılan bir çalışma ile de bu bulgular doğrulanmaktadır. Bu sonuçlar, bankaların ve diğer finansal kurumların ihtiyatsız davranışlarının etkili bir şekilde engellenmesini sağlamak için uygun bir finansal piyasa düzenlemesi ve denetiminin gerekli olduğu (Andersen ve Tarp 2003) görüşünü desteklemektedir.

Demirgüç-Kunt ve Detragiache (1998) de zayıf bir kurumsal ortamın ve uygun düzenleme ve denetim yokluğunun finansal krizlerin ortaya çıkmasını daha olası hale getirdiğine dair kanıtlar sunmaktadırlar. Kurumsal kalitenin, uygun düzenleme ve denetimin başarılı bir finansal liberalizasyon için önemli bir önkoşul olduğunu belirtmektedirler. Benzer şekilde Klein ve Olivei (2008), sermaye hesabının liberalleşmesinin finansal gelişmeyi teşvik ettiğini ancak bu sonucun kurumların, banka düzenlemelerinin ve denetimlerinin daha gelişmiş olduğu gelişmiş ülkeler için geçerli olduğunu belirtmektedirler. Daha düşük kurumsal kaliteye, banka düzenleme ve denetimine sahip olan gelişmekte olan ülkeler için sermaye hareketlerinin liberalizasyonu finansal gelişmeyi teşvik etmemektedir.

Diğer yandan finansal kriz literatürü, kredinin aşırı genişlemesine yol açabileceği için finansal liberalizasyonun istikrarı bozucu etkisine işaret etmektedir. İçsel büyüme literatürünün bulgularını vurgulayan araştırmacılar (Roubini ve Sala-i-Martin, 1992), finansal liberalleşmeyi ve derinleşmeyi savunurlarken krizlere odaklanan araştırmacılar ise "aşırı" finansal liberalleşmeye karşı uyarıda bulunmaktadırlar (Balino ve Sundarajan, 1991; Gavin ve Hausmann, 1995).

Sonuç olarak, literatürdeki son çalışmalar, finansal kurumların uygun şekilde düzenlenmesi ve denetimi sağlanmadan ve doğru kurumsal ortam hazırlanmadan finansal liberalleşmenin finansal gelişmenin artması beklentilerini karşılayamayacağına ve finansal kırılganlıkları 
artıracağına işaret etmektedir. Buradan hareketle finansal gelişme ve finansal kırılganlık arasındaki ilişkinin düzeyi, finansal kurumların uygun bir düzenleme ve denetleme yapısına sahip olduğu veya kurumsal ortamın sağlıklı işlediği konusunda da bilgiler verebilecektir. Yani, finansal gelişme ve finansal kırılganlık arasındaki ilişkinin ters yönlü olması kurumsal yapının sağlıklı olduğuna, aralarındaki pozitif bir ilişki ise bu ortamın düzenlenmesine ve denetlenmesine yönelik ihtiyacın yüksek olduğuna işaret edebilir.

\section{Türkiye'de Finansal Liberalizasyon Süreci ve Krizler}

Türkiye de diğer gelişmekte olan ülkeler gibi finansal serbestleşmenin sağlayacağ kazançlarından mahrum kalmamak için ve uluslararası konjonktürün de etkisiyle 1980 yılı itibariyle finansal liberalizasyon sürecine girmiştir. 24 Ocak 1980 kararları çerçevesinde diş ticaretin serbestleştirilmesiyle başlayan bu süreç 1989 yılında sermaye akımlarının serbestleştirilmesiyle tamamlanmıştır. 1980 öncesinde benimsenen ithal ikameci sanayileşme stratejisi ve devletin piyasalar üzerindeki düzenleyici ve denetleyici rolünün ağırlığı ihracattaki gelişmeleri engellemiş, dışa bağımlılık giderek artmış ve finansal piyasalar baskı altında kalmıştır. 1973 petrol krizi nedeniyle bozulan dış ticaret hadleri ve 1974 Kıbrıs Barış Harekatı'nın getirdiği mali yük, 1977 yılından başlayarak üç yıl etkisini sürdüren bir ekonomik kriz konjonktürünü ortaya çıkarmıştır (Akalın, 2006: 172). Bu kriz konjonktürüne ilişkin istikrar tedbirlerinin başarısız olması üzerine de 24 Ocak Kararları yürürlüğe konulmuştur. Finansal sistemin şekillenmesine önemli katkılar sağlayan 24 Ocak Kararları finansal sistem üzerindeki baskıların da kırılmasına neden olmuş ve bu kararlarla finansal piyasaların daha liberal olduğu yeni bir döneme geçiş yapılmıştır. Neo-liberal yaklaşıma dayanan 24 Ocak 1980 Kararları'nın Türkiye'de finansal liberalizasyon sürecinin başlangıcı olduğunu söylemek yerinde olacaktır.

Türkiye'de finansal liberalizasyon süreci aşamalı olarak gerçekleştirilmiştir. İlk olarak 1980 yılında faiz oranları üzerindeki denetimler kaldırılmış, bunu döviz kurları, finansal piyasalar ve bankacılık sektörü düzenlemeleri takip etmiştir. 1980-1989 döneminde yapılan bu düzenlemelerle iç finansal liberalizasyon gerçekleştirilmiştir. 1989'da ise sermaye hareketlerine yönelik düzenlemeler yapılarak dış finansal liberalizasyon da sağlanmıştır.

Döviz işlemlerinin ve sermaye hareketlerinin liberalizasyonu yurtdışından borçlanma imkanını artırmış ve bu yoldan sağlanan fonlar bankalar için önemli bir kaynak oluşturmuştur. 1993 yılında faiz oranlarının düşürülmesiyle fonların dövize ve borsaya yönelmesi döviz kurlarının aşırı yükselmesine neden olmuş ve Merkez Bankası'nın müdahaleleri başarısızlıkla sonuçlanmıştır. Bu durum ekonomideki belirsizliği ve dalgalanmaları hızlandırmıştır. 1993 
yılında borçlanma üst sınıra ulaşmış ve buna faiz oranlarının yeterince yükseltilememesi de eklenince 1994 yılı Nisan ayında bir kriz yaşanmıştır.

1995-1999 döneminde dünyada yaşanan Asya krizi, Rusya krizi ve Brezilya krizleri ile Türkiye'de yaşanan Marmara depremi, 1999 yılı sonunda Enflasyonu Düşürme Programı'nın yürürlüğe konulmasına yol açmıştır. Reel sektörün rekabet yapısını güçlendirmeyi, ekonomik dengesizlikleri gidermeyi hedefleyen bu program ile faiz oranları hızla düşürülmüş, enflasyon yüzde 30'un altına indirilmiş, üretim artırılmıştır. Ancak, aşırı değer kazanan TL, iç talebin hızlı artışı, ham petrol ve doğal gaz fiyatlarındaki yükselmeler gibi nedenler, 2000 yılında cari işlemler açığının beklentilerin çok üzerinde artmasına sebep olmuştur. İlave olarak yapısal reformların ve kamu bankalarına ilişkin düzenlemelerin tamamlanamaması, siyasi belirsizlikler, yabancı sermaye girişlerindeki düşüşler Kasım 2000'de yaşanan krize yol açmıştır. Bu kriz, finansal piyasalardaki risklerin artması yoluyla 2001 Şubat ayında ortaya çıkan yeni bir krizi tetiklemiştir.

2000 yılında uygulanan “döviz kuru çapasına dayalı enflasyonu düşürme” programının arka arkaya gelen krizler karşısında başarısız olması sonucunda 15 Mayıs 2001'de “Güçlü Ekonomiye Geçiş Programı” oluşturulmuştur. Bu istikrar programının hedefleri genel olarak, kamu iç borç dengesinin yeniden sağlanması, ekonominin dış desteğe ihtiyacının azaltılarak sağlıklı bir yapıya kavuşturulması, finansal piyasaların yeniden yapılandırılması, bankacılık kesimine işlerlik kazandırılması olarak ifade edilebilir. 2001 krizinden çıkarılan en önemli ders, sağlam bir finans sektörüne ve sağlam bir ekonomik yapıya sahip olmanın zorunluluğu olmuştur.

2001 krizi sonrasında finans sektörüne yönelik olarak alınan tedbirlerin başında finansal yapısı güçlü olmayan banka ve finansal kuruluşların sistem dışına çıkarılması ile kamu ve özel bankaların yapılarının güçlendirilmesine yönelik düzenlemelerin yapılması gelmiştir. $\mathrm{Bu}$ tedbirler birtakım eleştirilere maruz kalsa da yaşanan 2008 küresel krizi, finans sektörünün yapılandırılmasının ne kadar önemli olduğunu ve alınan tedbirlerin yerindeliğini göstermiştir.

Dünyada olduğu gibi Türkiye'de de finansal krizlerin çoğunlukla finansal liberalizasyon sonrası dönemde ortaya çıktığı görülmektedir. Makroekonomik istikrar sağlanmadan, yeterli yasal ve kurumsal düzenlemeler yapılmadan uygulanmaya başlanan finansal liberalizasyon hareketleri bu krizlerin temel nedenini oluşturmaktadır. Türkiye' de yaşanan krizlerin nedeni de finansal piyasaların etkin ve yeterince derin olmaması yanında sermaye hareketlerindeki serbestleşmenin gerektirdiği koşulların oluşturulamamasına bağlanabilir. Dolayısıyla finansal liberalizasyonun sermaye hareketlerinin serbestleşmesi yoluyla finansal gelişmeye olumlu 
katkılar yaparken gerekli yasal ve kurumsal düzenlemelerin eksikliği durumunda finansal kırılganlıklara ve krizlere yol açabileceği yaşanan tecrübeler sonucunda tespit edilmiştir.

\section{Türkiye'de Finansal Gelişme ve Finansal Kırılganlık İliş̧kisinin Ekonometrik Analizi}

Finansal kırılganlık ve finansal gelişme arasındaki ilişkilerin ekonometrik olarak tahminine geçilmeden önce bu değişkenlere ilişkin endekslerin hesaplanması gerekmektedir. Bu amaçla finansal kırılganlığın ve finansal gelişmenin göstergeleri niteliğinde olan çok sayıda değişken arasından istatistiksel olarak anlamlı olanlar belirlenmiş ve bu değişkenler kullanılarak endeksler oluşturulmuştur. Daha sonra ise hesaplanan finansal kırılganlık ve finansal gelişme endeksleri arasındaki uzun dönemli ilişkilerin tahminine geçilmiştir.

\subsection{Finansal Kırılganlık ve Finansal Gelişme Endekslerinin Oluşturulması}

Finansal kırılganlık ve finansal gelişmenin tek bir değişkenle ifade edilememesi nedeniyle literatürde bu kavramları açıklamak için farklı değişkenler kullanılmakta veya bu kavramları ölçmek için ilgili değişken setlerinden endeksler oluşturulmaktadır. Bazı çalışmalarda sadece bankacılık sektörü değişkenlerinin dikkate alındığını bazılarında ise hem bankacılık sektörü hem de sermaye piyasası değişkenlerinin ele alındığını görmek de mümkündür. Bunlardan Jung (1986), gelişmiş ve gelişmekte olan 56 ülkede finansal gelişme ve ekonomik büyüme arasındaki nedensellik ilişkisini incelediği çalışmada finansal gelişme göstergesi olarak $M_{0} / M_{1}$ ve $\mathrm{M}_{2} / \mathrm{GSYH}$ değişkenlerini kullanmıştır. $\mathrm{M}_{0} / \mathrm{M}_{1}$ oranı yani dolaşımdaki para miktarı arttıkça finansal varlık talebinin ve banka mevduat işlemlerinin azalacağını ve dolayısıyla finansal gelişmişlik düzeyinin düşeceğini gösterirken $\mathrm{M}_{2} / \mathrm{GSYH}$ oranındaki artışın finansal gelişme düzeyini yükselteceğini ifade etmektedir.

Lynch (1996) ise finansal gelişme ölçütlerini beş kategoride ele almıştır. Bunlar; miktar ölçütleri, yapısal ölçütler, finansal fiyatlama, ürün çeşitliliği ve işlem maliyetleridir. $\mathrm{M}_{1} / \mathrm{GSYH}$ ve özel sektöre açılan krediler/GSYH verilerini kullanan Lynch, parasal büyüklükler ile kredilere ilişkin büyüklükleri miktar ölçütleri olarak tanımlamıştır. Yapısal ölçüt değişkenleri olarak $\mathrm{M}_{2} / \mathrm{M}_{1}$, ihraç edilen menkul kıymetler/GSYH ve türev ürünler işlem hacmi/toplam vadeli işlem hacmi değişkenlerini kullanmıştır. Finansal fiyatlama ölçütü için de reel mevduat faiz oranını kullanmaktadır. Reel mevduat faiz oranının pozitif olması finansal gelişmenin önemli bir koşuludur. Ürün çeşitliliği kategorisinde ise finansal gelişmişliğin artmasıyla finansal risklerin daha etkin değerlendirilebileceğini ve asimetrik bilginin azalmasıyla finansal ürün çeşitliliğinin artacağını belirtmektedir. İşlem maliyetleri kapsamında ise düşük finansal aracılık işlemlerinin finansal gelişmeyi artıran önemli bir faktör olduğuna işaret etmektedir. Von Furstenberg ve Fratianni (1996) ise 1994 Meksika krizi dönemini analiz ettikleri çalışmada 
finansal gelişmişliğin göstergesi olarak, $\mathrm{M}_{3} / \mathrm{GSYH}$, özel sektöre açılan krediler/GSYH, bankacılık aktifleri/GSYH ve borsa kapitalizasyonu/GSYH oranlarını kullanmışlardır.

Finansal kırılganlığı açıklamak için ise Barışık ve Demirel (2014) Türkiye'de döviz kuru baskısını ve Kredi Temerrüt Takası (Credit Default Swap-CDS) primlerini kullanırken Demirgüç-Kunt ve Detragiachi (1998), bankacılık krizlerinin oluşmasında makroekonomik faktörlere dikkat çekmişlerdir. Düşük büyüme oranı, kredi riski ve borçluların temerrüde düşme olasılıkları finansal kırılganlığı artıran ve krize neden olan önemli unsurlardır. Rossi (1999), 1990-1997 dönemi için 15 gelişmekte olan ülke ekonomisini incelediği çalışmada finansal kırılganlık göstergeleri olarak, bankacılık rezervleri ve kredilere ilişkin değişkenleri kullanmıştır. Ahumoda ve Budnevich (2002) ise Şili bankacılık sisteminde finansal kırılganlığı, temerrüde düşmüş kredilerin toplam krediler içerisindeki payı ve interbank primleri ile ifade etmişlerdir. Ertuğrul ve Yeldan (2003) da Türkiye için yaptıkları çalışmada finansal kırılganlık göstergesi olarak yabancı para (YP) mevduatı/toplam mevduat oranını kullanmışlar ve bu orandaki artışın finansal kırılganlığa ivme kazandırdığına dikkat çekmişlerdir.

Hawkins ve Klau (2000), yükselen piyasa ekonomilerinde bankacılık sistemi için oluşturdukları kırılganlık endeksinde, bankaların dış borçları/yurtiçi krediler, yurtiçi kredi büyüme oranı, yabancı bankalardan borçlanma düzeyi, reel faiz oranı ve bankaların kredi derecelerini kullanmışlardır. Türkiye’de 1990-2014 döneminde finansal gelişme ve finansal kırılganlık arasındaki ilişkiyi inceleyen Varlık (2015) da finansal kırılganlık endeksi için özel sektöre açılan krediler, merkez bankası brüt döviz rezervleri/ $\mathrm{M}_{2}$, bankaların dış yükümlülükleri, bankacılık rezervleri/toplam aktif, mevduat/toplam aktif, takipteki krediler/toplam aktif, diş yükümlülükler/ $\mathrm{M}_{2}$ ve yabancı mevduat/toplam mevduat değişkenlerini kullanmıştır. Finansal gelişme endeksi için ise mevduatlar/GSYH, bankacılık toplam aktif/GSYH, $\mathrm{M}_{2} / \mathrm{GSYH}$, $\mathrm{M}_{3} / \mathrm{GSYH}$, Bist100, $\mathrm{M}_{0} / \mathrm{M}_{1}$, borsa kapitalizasyonu ve kredi büyümesi değişkenlerini ele almıştır.

Finansal kırılganlık ve finansal gelişmeyi belirleyen çok sayıda değişken olduğu literatürdeki çalışmalardan da anlaşılmaktadır. Dolayısıyla bu çalışmada sapmasız tahmin sonuçları elde edebilmek amacıyla literatürde yer alan değişkenler mümkün olduğunca analize dahil edilmeye çalışılmıştır. Çalışmada, endekslerde kullanılan değişkenlere ilişkin veri kısıtlılıkları nedeniyle 2007Q1-2019Q2 dönemi dikkate alınmış olup finansal gelişme ve finansal kırılganlık endeksleri Temel Bileşenler Analizi (Principal Component Analysis-PCA) kullanılarak belirlenmiştir. Endekslere dahil edilen bazı değişkenlerin PCA analizi esnasında dışlanması nedeniyle sonuç olarak finansal gelişme endeksi için 10 ve finansal kırılganlık endeksi için de 12 değişken kullanılmıştır (Tablo 1). Değisşkenler, Türkiye Cumhuriyet Merkez 
Bankası (TCMB) Elektronik Veri Dağıtım Sistemi (EVDS), Bankacılık Düzenleme ve Denetleme Kurumu (BDDK), Sermaye Piyasası Kurulu (SPK), Hazine ve Maliye Bakanlığı kaynaklarından elde edilmiştir.

Tablo 1. Finansal Kırılganlık ve Finansal Gelişme Endeksi Değişkenleri

\begin{tabular}{|l|l|l|l|}
\hline \multicolumn{2}{|c|}{ Finansal Kırılganlık } & \multicolumn{2}{c|}{ Finansal Gelişme } \\
\hline KNBS/GSYH & Kamu net borç stoku/GSYH & ÖSK/GDP & Özel sektör kredileri/GSYH \\
\hline FDBH/GSYH & $\begin{array}{l}\text { Faiz dişı bütçe } \\
\text { harcamaları/GSYH }\end{array}$ & TK/GSYH & Toplam kredi/GSYH \\
\hline CD/GSYH & Cari denge/GSYH & TM/GSYH & Toplam mevduat/GSYH \\
\hline İÇ/GSYH & İç borç stoku/GSYH & NDYY/GSYH & $\begin{array}{l}\text { Net doğrudan yabancı } \\
\text { yatırım/GSYH }\end{array}$ \\
\hline BO & Büyüme oranı & MBDR/GSYH & $\begin{array}{l}\text { Merkez bankası döviz } \\
\text { rezervleri/GSYH }\end{array}$ \\
\hline MVD/TA & $\begin{array}{l}\text { Toplam mevduat/Toplam } \\
\text { aktifler }\end{array}$ & KRD/MVD & $\begin{array}{l}\text { Toplam kredi/Toplam } \\
\text { mevduat }\end{array}$ \\
\hline TK/TA & Takipteki krediler/Toplam aktif & TA/GSYH & Toplam aktif/GSYH \\
\hline UYP/GSYH & $\begin{array}{l}\text { Uluslararası yatırım } \\
\text { pozisyonu/GSYH }\end{array}$ & İEMK/GSYH & $\begin{array}{l}\text { İhraç edilen menkul } \\
\text { kiymetler/GSYH }\end{array}$ \\
\hline YP/TM & $\begin{array}{l}\text { Yabanc1 mevduat/Toplam } \\
\text { mevduat }\end{array}$ & Bist100/GSYH & Bist100/GSYH \\
\hline KVDB/MBDR & $\begin{array}{l}\text { Kisa vadeli diş borç/Merkez } \\
\text { bankası döviz rezervleri }\end{array}$ & M2/GSYH & M2 para arzı/GSYH \\
\hline REDK & Reel efektif döviz kuru & & \\
\hline İTH/İHR & İthalat/İhracat & & \\
\hline
\end{tabular}

PCA, değişken azaltma analizi olarak da tanımlanmaktadır. Çünkü bu yöntemde çok sayıda değişkenin oluşturduğu veri setiyle anlatılmak istenen daha az sayıdaki bileşene indirgenerek ifade edebilmektedir (Dunteman, 1989:8). Değişkenler arasında çok yükssek ya da çok düşük düzeyde ilişki bulunması faktör sonuçlarını etkilemektedir. $\mathrm{Bu}$ nedenle değişken seçimi oldukça önemlidir. İlişkinin yüksek olması, çoklu bağıntı (multicollinearity) sorununu doğuracağından veri uygunluğu testlerinin yapılması ve çok yüksek veya çok düşük ilişkili değişkenlerin analizden çıkarılması önemlidir (OECD, 2005: 40-41). Veri uygunluğu testlerinden biri olan Kaiser-Meyer-Olkin (KMO) testi, değişkenler arasındaki ilişkilerin önem derecesini ve kullanılan verilerin analize uygunluğunu göstermektedir. KMO testinin 0,60’tan büyük olması seçilen değişkenlerin uygun olduğunu ifade etmektedir. $\mathrm{H}_{0}$ hipotezi “Korelasyon matrisi birim matrise eşittir" şeklinde kurulan Bartlett Testi'nde ise bu hipotezin reddedilmesi, değişkenler arasında korelasyonun 1.00'den farklı olduğu anlamına gelmektedir. Bu durumda değişkenler arasındaki ilişkilerin önemli olduğu sonucuna ulaşılır.

Bunun yanında öz değeri 1'den büyük olan bileşenler, faktör sayısının belirlenmesi için yeterli olduğundan öz değeri 1'den küçük olan bileşenler dikkate alınmamaktadır. Tablo 2 ve 3'te sırasıyla finansal kırılganlık ve finansal gelişme değişkenlerinin analiz için uygun olduğunu gösteren KMO ve Bartletts test değerleri, özdeğerler ve varyans açıklama oranları 
gösterilmiştir. İncelenen 12 adet finansal kırılganlık değişkenleri için bulunan KMO test değeri \%72,9 ve finansal gelişme değişkenleri için bulunan KMO test değeri ise \%72,4 tür. $\mathrm{Bu}$ değerlerin \%60'dan büyük olması veri setinin temel bileşenler analizi için iyi derecede uygun olduğunu ifade etmektedir. Bartlet testi sonuçları da hem finansal gelişme hem de finansal kırılganlık değişkenleri arasındaki ilişkilerin önemli olduğunu desteklemektedir.

Tablo 2'de 12 temel bileşenden sadece üç tanesinin özdeğerinin 1'den büyük olduğu gözlenmektedir. Birinci temel bileșen toplam varyansın \%47,889'unu, ikinci temel bileșen \%24,302'sini, üçüncü temel bileşen ise \%8,346'sını açıklarken üç bileşen birlikte toplam varyansın \%80,537'sini açıklamaktadır. Bu sonuç, 12 değişkenle anlatılmak istenen finansal kırılganlığın üç bileşen altında toplandığını göstermektedir. Böylece üç temel bileşenin ağırlıkları alınarak finansal kırılganlık endeksi oluşturulmuştur. Tablo 3'te ise 10 temel bileşenden sadece iki tanesinin özdeğeri 1'den büyüktür. Dolayısıyla iki bileşen birlikte toplam varyansın \%76,011'ini açıklamakta olup finansal gelişmişlik endeksinin oluşturulmasında bu iki temel bileşenin ağırlıkları alınmıştır.

Tablo 2. Finansal Kırılganlık Değişkenleri için KMO Testi ve Varyans Açıklama Oranları

\begin{tabular}{|c|c|c|c|c|c|c|}
\hline \multicolumn{4}{|c|}{$\begin{array}{l}\text { Kaiser-Meyer-Olkin Testi } \\
\text { Bartlett Testi }\end{array}$} & \multicolumn{2}{|c|}{$\begin{array}{l}\text { Ki-kare } \\
\text { Serbestlik derecesi } \\
\text { Anlamlılık düzeyi }\end{array}$} & $\begin{array}{r}0,729 \\
661,115 \\
66 \\
, 000\end{array}$ \\
\hline \multicolumn{7}{|c|}{ Açıklanan Toplam Varyans } \\
\hline \multirow[b]{2}{*}{ Bileşen } & \multicolumn{3}{|c|}{ Özdeğerler } & \multicolumn{3}{|c|}{ Kareli Yükler Toplamı } \\
\hline & Toplam & $\begin{array}{c}\text { Varyans } \\
\%\end{array}$ & $\underset{\%}{\text { Kümülatif }}$ & Toplam & $\begin{array}{c}\text { Varyans } \\
\%\end{array}$ & $\underset{\%}{\text { Kümülatif }}$ \\
\hline 1 & 5,747 & 47,889 & 47,889 & 5,747 & 47,889 & 47,889 \\
\hline 2 & 2,916 & 24,302 & 72,191 & 2,916 & 24,302 & 72,191 \\
\hline 3 & 1,002 & 8,346 & 80,537 & 1,002 & 8,346 & 80,537 \\
\hline 4 &, 855 & 7,124 & 87,661 & & & \\
\hline 5 & ,509 & 4,241 & 91,902 & & & \\
\hline 6 & ,383 & 3,191 & 95,093 & & & \\
\hline 7 & 221 & 1,844 & 96,936 & & & \\
\hline 8 & ,137 & 1,141 & 98,077 & & & \\
\hline 9 & ,124 & 1,031 & 99,108 & & & \\
\hline 10 & ,052 &, 434 & 99,541 & & & \\
\hline 11 & ,041 & ,341 & 99,882 & & & \\
\hline 12 & ,014 & ,118 & 100,000 & & & \\
\hline
\end{tabular}


Tablo 3. Finansal Gelişme Değişkenleri için KMO Testi ve Varyans Açıklama Oranları

\begin{tabular}{|c|c|c|c|c|c|c|}
\hline \multicolumn{4}{|c|}{$\begin{array}{l}\text { Kaiser-Meyer-Olkin Testi } \\
\text { Bartlett Testi }\end{array}$} & \multicolumn{2}{|c|}{$\begin{array}{l}\text { Ki-kare } \\
\text { Serbestlik dereces } \\
\text { Anlamll1ık düzeyi }\end{array}$} & $\begin{array}{r}0,724 \\
1082,638 \\
45 \\
, 000\end{array}$ \\
\hline \multicolumn{7}{|c|}{ Açıklanan Toplam Varyans } \\
\hline \multirow[b]{2}{*}{ Bileşen } & \multicolumn{3}{|c|}{ Özdeğerler } & \multicolumn{3}{|c|}{ Kareli Yükler Toplamı } \\
\hline & Toplam & $\begin{array}{c}\text { Varyans } \\
\%\end{array}$ & $\begin{array}{c}\text { Kümülatif } \\
\%\end{array}$ & Toplam & $\begin{array}{c}\text { Varyans } \\
\%\end{array}$ & $\begin{array}{c}\text { Kümülatif } \\
\%\end{array}$ \\
\hline 1 & 6,312 & 63,123 & 63,123 & 6,312 & 63,123 & 63,123 \\
\hline 2 & 1,289 & 12,888 & 76,011 & 1,289 & 12,888 & 76,011 \\
\hline 3 & ,981 & 9,811 & 85,822 & & & \\
\hline 4 & 644 & 6,439 & 92,260 & & & \\
\hline 5 & ,473 & 4,726 & 96,987 & & & \\
\hline 6 & ,278 & 2,783 & 99,770 & & & \\
\hline 7 & ,014 & 142 & 99,913 & & & \\
\hline 8 & 005 & 051 & 99,964 & & & \\
\hline 9 & ,003 & ,034 & 99,998 & & & \\
\hline 10 & ,000 & ,002 & 100,000 & & & \\
\hline
\end{tabular}

Temel bileşenler analizi yöntemiyle endeks oluşturulmasının bir diğer avantajı bileşenlerin yük matrisinin hesaplanabilmesidir. Bileşenlerin yük matrisi, her bir değişkenin temel bileşenlerdeki ağırlığını ve bu ağırlığın yönünü vermektedir. Eğer bileşen yükü pozitif işarete sahip ise aynı yönde bir ilişkinin olduğu söylenir. Kavramsal olarak bu ilişki, temel bileşenlerin açıkladığı boyut ile değişkenler arasında görülen istatistiksel bağıntı yapısını ifade etmektedir (Y1kmaz, 2011: 111).

Tablo 4'te yer alan finansal kırılganlık değişkenleri yük matrisi sonuçları, birinci temel bileşende yer alan 12 değişkenden 8'inin finansal kırılganlık düzeyi ile aynı yönde, 4'ünün zıt yönde ilişkili olduğunu göstermektedir. İkinci temel bileşende yer alan 11 değişkenden 7'si finansal kırılganlık ile aynı yönde 4'ü zıt yöndedir ve cari denge/GSYH değişkeni en yüksek değeri almıştır. Üçüncü temel bileşende ise en yüksek yük matrisi değerini faiz dışı bütçe dengesi/GSYH değişkeni almıştır. Dolayısıyla yük matrisi tablosuna göre cari denge/GSYH değişkeninin ikinci bileşenle, faiz dışı bütçe dengesi/GSYH değişkeninin ise üçüncü bileşenle açıklandığı söylenebilir. Finansal kırılganlık endeksi (FKE) bu üç bileşen birlikte ele alınarak oluşturulmuştur.

Finansal gelişme değişkenleri yük matrisi sonuçları ise birinci temel bileşende yer alan 9 değişkenden 8'inin finansal gelişmişlik düzeyi ile aynı yönde, 1'inin zıt yönde ilişkili olduğunu göstermektedir. İkinci temel bileşendeki 9 değişkenin ise 6's1 aynı yönde iken 3'ü zıt yöndedir. Birinci bileşende yer almayan Bist100/GSYH oranı ikinci bileşende yer almaktadır ve finansal gelişmişlik düzeyi ile zıt yönlü ilişkisi bulunmaktadır. Finansal gelişme endeksi (FGE) bu iki bileşenin birlikte ele alınmasıyla oluşturulmuştur. 
Tablo 4. Finansal Kırılganlık ve Gelişme Değişkenleri Yük Matrisi

\begin{tabular}{|c|c|c|c|c|c|c|}
\hline \multirow{2}{*}{$\begin{array}{l}\text { Finansal } \\
\text { Kırılganlık } \\
\text { Değişkenleri }\end{array}$} & \multicolumn{3}{|c|}{ Bileşenler } & \multirow{2}{*}{$\begin{array}{l}\text { Finansal } \\
\text { Gelişme } \\
\text { Değișkenleri }\end{array}$} & \multicolumn{2}{|c|}{ Bileşenler } \\
\hline & 1 & 2 & 3 & & 1 & 2 \\
\hline İÇS/GSYH & ,918 & ,275 &,- 146 & TA/GSYH & ,988 & \\
\hline KVDB/MBDR &,- 900 &,- 273 & & TK/GSYH & ,977 & , 107 \\
\hline MVD/TA & ,836 & ,419 &,- 125 & ÖSK/GSYH & ,969 &, 125 \\
\hline KNBS/GSYH & 807 & ,423 & & TM/GSYH & 967 &,- 143 \\
\hline YP/TM &,- 788 & ,308 & ,333 & KRD/MVD & ,924 & ,211 \\
\hline TK/TA &,- 700 & ,242 &,- 456 & M2/GSYH & 914 &,- 234 \\
\hline UYP/GSYH & 681 & ,479 & 226 & NDYY/GSYH &,- 652 & ,382 \\
\hline REDK &, 529 & &,- 272 & İEMK/GSYH & ,508 & , 324 \\
\hline BO & 146 &,- 891 &,- 107 & BİST100/GSYH & &,- 869 \\
\hline CD/GSYH & - ,561 & ,780 & & MBDR/GSYH & ,361 & ,365 \\
\hline İTH/İHR &, 570 &,- 762 & & & & \\
\hline FDBD/GDP & ,477 &,- 216 & ,704 & & & \\
\hline
\end{tabular}

Sonuç olarak, elde edilen faktör yükleri matrisi, faktörlerin varyans açıklama oranları dikkate alınarak ağırlıklandırılmıştır. Yani her bir faktör stokları matrisi varyans açıklama oranları ile çarpılıp toplanarak finansal kırılganlık ve finansal gelişme endeksleri elde edilmiş ve Şekil 1'de gösterilmiştir.

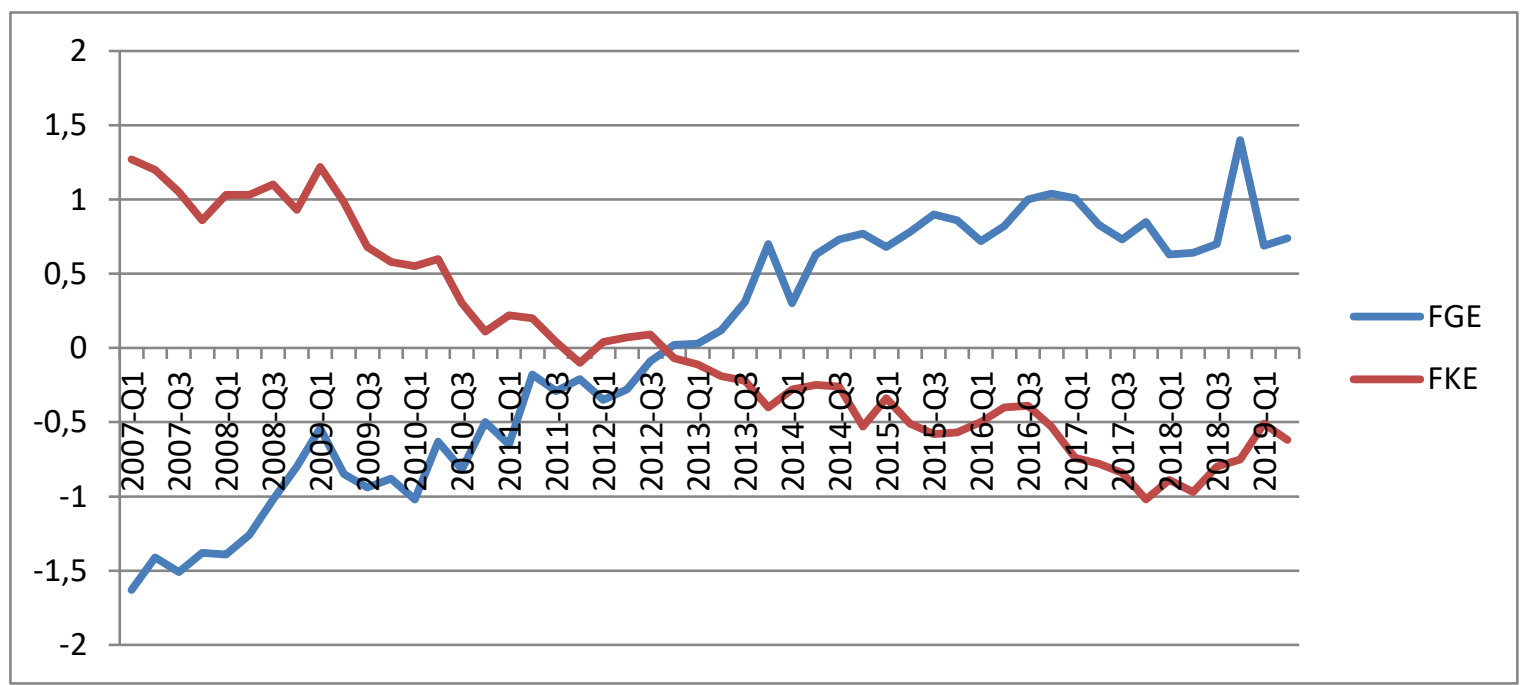

Şekil 1. Finansal Kırılganlık ve Finansal Gelişme Endeksi

Şekil 1'den Türkiye'de 2007 sonrasında finansal gelişme seyrinin giderek yükselme eğiliminde olduğunu söylemek mümkündür. 2012'nin son çeyreğine kadar ortalamanın altında seyreden FGE, 2008 küresel krizinin ve devamındaki Avrupa Borç krizinin de olumsuz etkilerini yansıtmaktadır. 2012 yılından sonra ise finansal gelişme düzeyi ortalamanın üzerinde seyretmektedir. FKE’nin ise aksine ortalamanın üstünde seyretmekle birlikte giderek azaldığ ve 2012 yılının son çeyreğinden sonra ortalamanın altına indiği görülmektedir. Bu durum, 
finansal gelişme arttıkça finansal kırılganlığın azaldığını göstermesi açısından önemlidir. 2001 krizinden sonra Türkiye'de uygulamaya konulan yapısal reformların finansal sistemin güçlendirilmesine katkı sağladığını, kurumsal düzenlemelerin gerçekleştirilmesinde ve finansal kırılganlığın azaltılmasında önemli rol oynadığını ifade etmek mümkündür. Nitekim dünya ülkelerinin önemli ölçüde etkilendiği 2008 krizinden Türkiye’nin daha az oranda etkilenmiş olması bir tesadüf olmamalıdır.

TCMB'nin 2010 yılının son çeyreğinden itibaren yeni para politikası anlayışı çerçevesinde fiyat istikrarından ödün vermeden finansal istikrarı sağlamaya yönelik olarak konjonktürel para politikası araçlarına (politika faiz oranı, faiz koridoru vb.) ilaveten yapısal para politikası araçlarını (vadeye dayalı zorunlu karşılıklar, kaldıraca dayalı zorunlu karşılıklar ve rezerv opsiyon mekanizması gibi) uygulamaya koyması, 2012 yılının son çeyreğinden sonra FGE'nin ortalamanın üzerinde seyretmesinin ve FKE'nin ortalamanın altına inmesinin arkasındaki önemli bir neden olarak değerlendirilebilir. Ancak, 2018 yılında yaşanan döviz kuru şoku ile ortaya çıkan makroekonomik göstergelerdeki bozulmaların son dönemde FKE’nin yukarı yönlü hareketine neden olduğu da gözlenmektedir.

\subsection{Ekonometrik Yöntem ve Bulgular}

Türkiye için 2007Q1-2019Q2 döneminde çeyreklik veriler kullanılarak oluşturulan finansal kırılganlık ve finansal gelişme endeksi arasındaki uzun dönemli ilişki, Pesaran vd. (2001) tarafından geliştirilen ARDL sınır testi ile tahmin edilmiştir. Zaman serisi analizlerinde, değişkenler arasındaki ilişkilerin anlamlılığı açısından durağanlık sınamalarının yapılması önemlidir. Literatürde serilerin durağanlıklarının araştırılması konusunda en yaygın kullanılanlar Genişletilmiş Dickey Fuller (ADF) ve Phillips Perron (PP) birim kök testleridir. ADF testine göre FKE ve FGE, düzeyde durağan değildirler. Ancak birinci farklarında durağan hale gelmektedirler (Tablo 5).

Tablo 5. Birim Kök Analizi

\begin{tabular}{|l|l|l|}
\hline \multirow{2}{*}{ Değişkenler } & \multicolumn{2}{c|}{ ADF Testi } \\
\cline { 2 - 3 } & \multicolumn{1}{|c|}{ Düzey Hali } & \multicolumn{1}{c|}{ Birinci Farkı } \\
\hline FKE & $-1.519428(0.8093)$ & $\mathbf{- 6 . 8 2 0 5 7 4 ( 0 . 0 0 0 0})^{*}$ \\
\hline FGE & $-1.252424(0.8876)$ & $\mathbf{- 9 . 9 1 3 3 3 5 ( 0 . 0 0 0 0})^{*}$ \\
\hline Anlamlılık Düzeyi & \multicolumn{2}{|c|}{ Kritik Değerler } \\
\hline $1 \%$ & -4.156734 & -4.161144 \\
\hline $5 \%$ & -3.504330 & -3.506374 \\
\hline $10 \%$ & -3.181826 & -3.183002 \\
\hline
\end{tabular}


ARDL sinır testi yöntemiyle test edilecek modeller Denklem 1 ve Denklem 2'de yer almaktadir.

Model I : $f k e=\alpha_{1}+\beta_{1} f g e_{t}+\epsilon_{1 t}$

Model II : $f g e=\alpha_{2}+\beta_{2} f g e_{t}+\epsilon_{2 t}$

Burada fke ve fge sırasıyla finansal kırılganlık endeksi ve finansal gelişme endeksini, $\alpha_{1}$ ve $\alpha_{2}$ sabit terimi, $\beta_{1}$ ve $\beta_{2}$ değişkenlere ait tahmin katsayılarını, $\epsilon_{1 \mathrm{t}}$ ve $\epsilon_{2 \mathrm{t}}$ ise hata terimlerini ifade etmektedir.

Sınır testi yönteminin uygulanması için öncelikle kısıtlanmamış bir hata düzeltme modelinin kurulması gerekmektedir (Denklem 3 ve 4).

Model I: $\Delta f k e_{t}=\alpha_{1}+\lambda_{1} f k e_{t-1}+\lambda_{2} f g e_{t-1}+\sum_{i=1}^{m} \theta_{i} \Delta f k e_{t-i}+\sum_{i=1}^{m} \emptyset_{i} \Delta f g e_{t-i}+u_{1 t}$

Model II: $\Delta f g e_{t}=\alpha_{2}+\lambda_{1} f g e_{t-1}+\lambda_{2} f k e_{t-1}+\sum_{i=1}^{m} \emptyset_{i} \Delta f g e_{t-i}+\sum_{i=1}^{m} \theta_{i} \Delta f k e_{t-i}+u_{2 t}$

Denklem 3 ve 4 'te yer alan $\Delta$ ilgili değişkenlerin birinci farklarını, m optimal gecikme uzunluklarını, $\alpha_{1}$ ve $\alpha_{2}$ sabit terimi, $\lambda_{i}(\mathrm{i}=1,2)$ gecikmeli düzey değişkenlerin parametresini, $\theta_{i}$ ve $\emptyset_{i}(\mathrm{i}=1,2 \ldots \mathrm{m})$ ise gecikmeli fark değişkenlerin katsayılarını tanımlamaktadır. Model I'de uygun gecikme uzunlukları fke için 1, fge için 2 olarak bulunmuştur. Model II'de ise gecikme uzunlukları fge için 2 ve fke için 2 olarak belirlenmiştir. Denklem 3 ve 4 'teki modeller bu gecikme uzunluklarıyla tahmin edildikten sonra F istatistiği değerleri kullanılarak değişkenler arasında eşbütünleşme ilişkisi olup olmadığı tespit edilmektedir. Pesaran vd. (2001) tarafından oluşturulan alt ve üst sınır kritik değerleri, hesaplanan $F$ istatistiği değerleri ile karşılaştırılmaktadır. Hesaplanan F istatistiği değerinin alt kritik değerden küçük olması durumunda seriler arasında eşbütünleşme ilişkisi olmadığı, hesaplanan F istatistiği değerinin üst kritik değerden büyük olması durumunda da seriler arasında eşbütünleşme ilişkisi bulunduğu sonucuna ulaşılmaktadır. Hesaplanan F istatistiği değerinin alt ve üst kritik değerleri arasında kalması durumda ise eşbütünleşme ilişkisi konusunda kesin bir yorum yapilamamaktadir.

ARDL tahmini sonucu her iki model için elde edilen F-istatistiği değerlerinin Pesaran vd. (2001) tarafından \%5 anlamlılık düzeyinde oluşturulan üst sınır değerinden (4.16) büyük olduğu görülmektedir (Tablo 6). Bu durum, $\mathrm{H}_{0}$ hipotezinin reddedilmesi yani değişkenler arasında bir eşbütünleşme ilişkisinin var olduğunun kabul edilmesi anlamına gelmektedir. Özet olarak, her iki modele göre de finansal kırılganlık endeksi ile finansal gelişme endeksi arasında uzun dönemde bir eşbütünleşme ilişsisi mevcuttur. 
Tablo 6. ARDL Sınır Testi Sonuçları

\begin{tabular}{|c|c|c|c|c|c|}
\hline & k & F istatistiği & Optimum Gecikme & \multicolumn{2}{|c|}{ \%5 Kritik Değer } \\
Uzunluğu & Alt Sınır & Üst Sınır \\
\hline Model I & 1 & 6.526 & $(1,2)$ & & \\
Model II & 1 & 5.374 & $(2,2)$ & 3.62 & 4.16 \\
\hline
\end{tabular}

Not: k bağımsız değişken sayısını temsil etmektedir. Kritik değerler Peseran vd. (2001) Tablo CI(iii)'den alınmıştır.

Modellerin otokorelasyon ve değişen varyans sorunu içerip içermedikleri de araştırılmıştır. Otokorelasyon hata teriminin birbirini izleyen değerleri arasındaki anlamlı ilişkiyi ve değişen varyans ise hata teriminin varyansının tüm gözlemler için aynı olmaması durumunu ifade etmektedir. Değişen varyans için Breusch-Pagan-Godfrey ve Otokorelasyon sorunu için de Breusch-Godfrey LM Testi kullanılmış olup her iki sorunun da bulunmadığı tespit edilmiştir (Tablo 7).

Tablo 7. Değișen Varyans ve Otokorelasyon Testleri

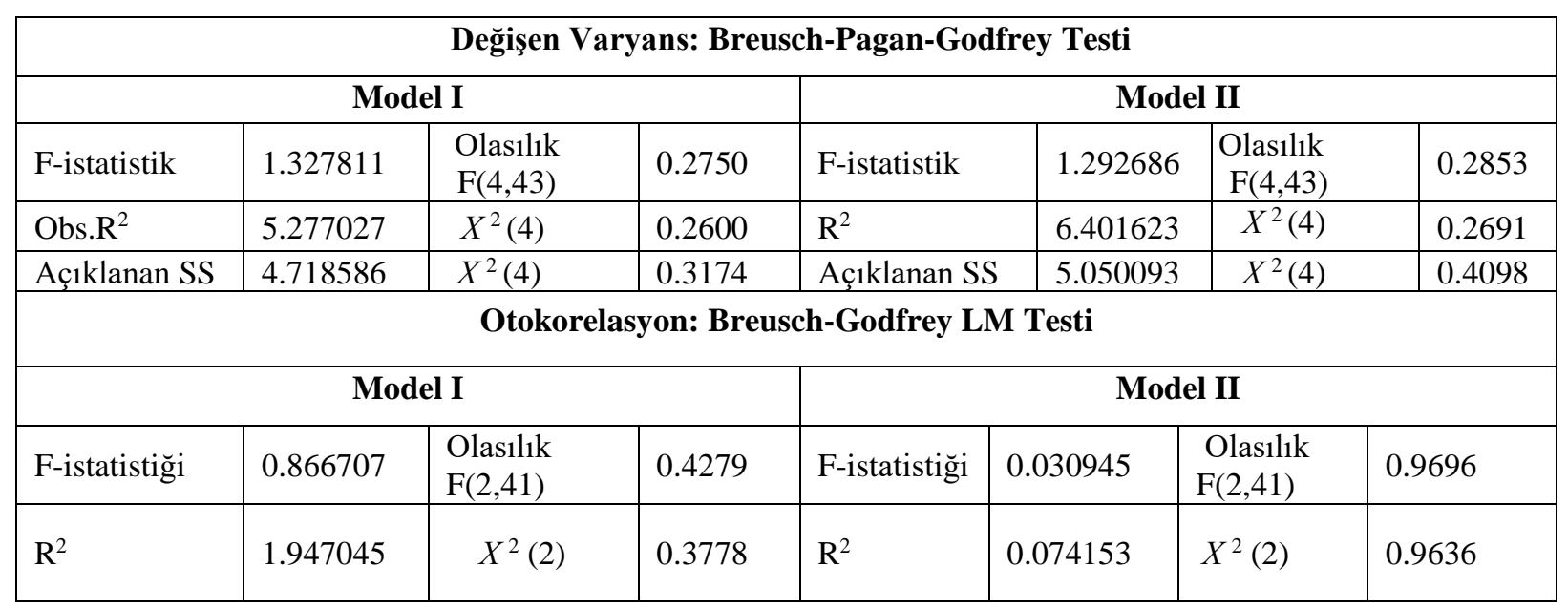

Değişkenler arasındaki uzun dönemli ilişkilerin incelenmesine yönelik oluşturulan modeller ise Denklem 5 ve 6'da yer almaktadır.

Model I: $\Delta f k e_{t}=\alpha_{1}+\sum_{i=1}^{m} \theta_{i} \Delta f k e_{t-i}+\sum_{i=1}^{m} \emptyset_{i} \Delta f g e_{t-i}+\epsilon_{1 t}$

Model II: $\Delta f g e_{t}=\alpha_{2}+\sum_{i=1}^{m} \emptyset_{i} \Delta f g e_{t-i}+\sum_{i=1}^{m} \theta_{i} \Delta f k e_{t-i}+\epsilon_{2 t}$

Her iki modelin tahmin sonuçlarına göre (Tablo 8) finansal kırılganlık ile finansal gelişme arasında uzun dönemde negatif yönlü bir ilişki bulunmaktadır. Model I'de FGE'deki bir birimlik artış FKE’yi yaklaşık 0.6 birim azaltmaktadır ve bu ilişki \%1 düzeyinde anlamlıdır. Model II'de ise FKE'de ortaya çıkan bir birimlik artış FGE'yi 0.8 birim azaltmaktadır ve bu ilişkinin anlamlılık düzeyi ise \%5'tir. Dolayısıyla uzun dönemde finansal kırılganlık ile finansal gelişme arasında güçlü bir ilişki olduğu sonucuna varılabilir. 
Tablo 8. ARDL Uzun Dönem Katsayıları

\begin{tabular}{|l|l|l|l|l|}
\hline \multicolumn{5}{|l|}{ Model I } \\
\hline Bağımlı değişken fke & Katsayı & Standart Hata & t-istatistik & Olasılık \\
\hline Değişkenler & -0.598872 & 0.122456 & -4.890527 & 0.0000 \\
\hline fge & -0.315453 & 0.152122 & -2.073688 & 0.0441 \\
\hline sabit & Model II & t-istatistik & Olasılık \\
\hline \multicolumn{5}{|l|}{} \\
\hline Bağımlı değişken fge & Katsayı & Standart Hata & -2.242944 & 0.0302 \\
\hline Değişkenler & -0.784726 & 0.349864 & 1.441643 & 0.1568 \\
\hline fke & 0.568837 & 0.394575 &
\end{tabular}

Değişkenlerin istikrar düzeylerinin belirlenmesinde CUSUM ve CUSUMSQ testleri kullanılmaktadır. İstatistik değerlerinin \%5 anlam düzeyinde kritik sınırlar (kırmızı iki çizgi arasında) içerisinde kalması, katsayıların istikrarlı olduğu hipotezinin $\left(\mathrm{H}_{0}\right)$ kabul edilmesi anlamına gelmektedir. Şekil 2'de yer alan CUSUM ve CUSUMSQ grafikleri Model I için değişkenlerin istikrarlı olduğuna işaret etmektedir. Model II'deki değişkenler ise CUSUM grafiğine göre, 2007-2019 döneminde istikrarlı ancak CUSUMSQ sonuçlarına göre 2015Q22018Q3 döneminde istikrarsızdır. Bu durum, söz konusu dönemde Türkiye' de yaşanan terör olayları, darbe girişimi, kurdaki ani yükselişler vs. gibi nedenlerle açıklanabilir.
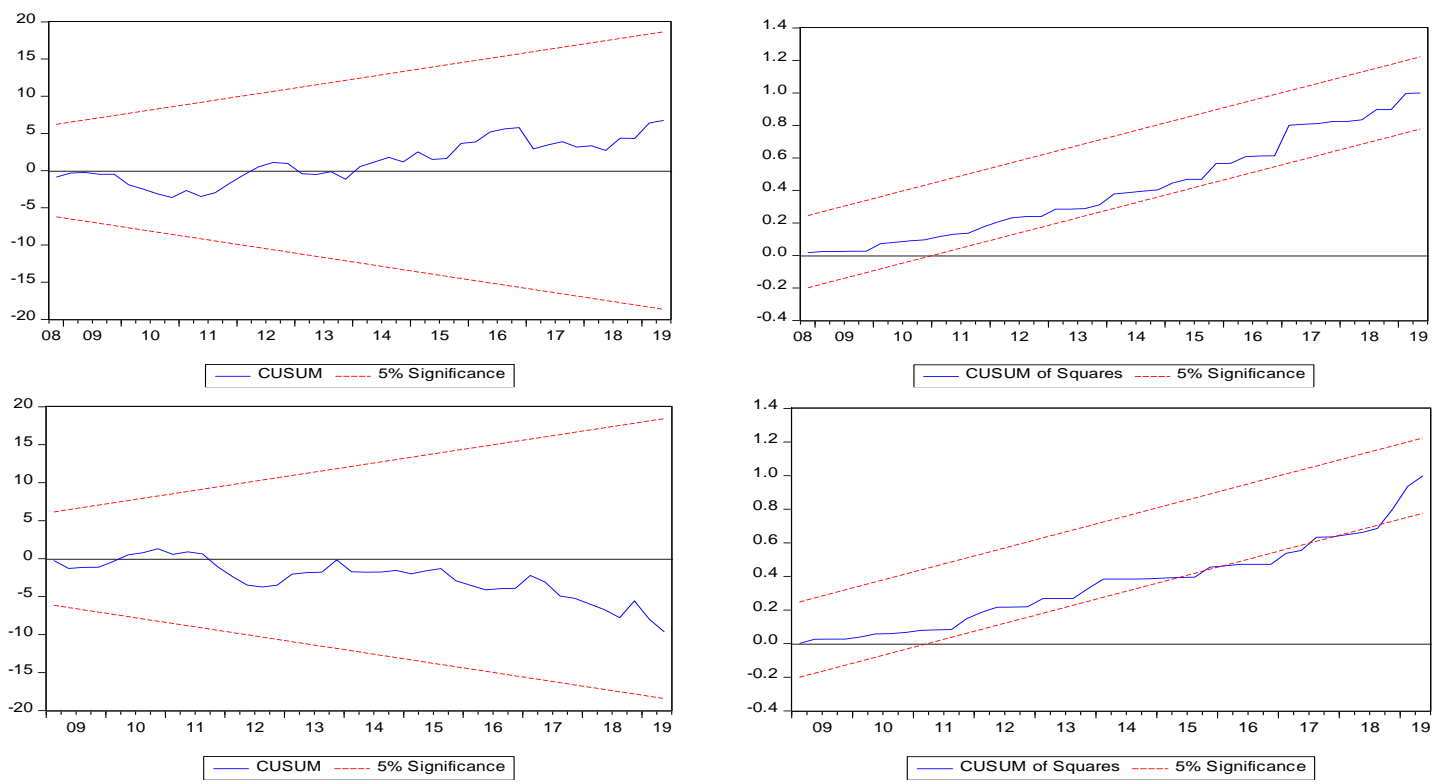

Şekil 2. Model I ve Model II için CUSUM ve CUSUMSQ Grafikleri

Değişkenler arasındaki kısa dönemli ilişkiler hata düzeltme modeli (ECM) ile tahmin edilmektedir (Denklem 7 ve 8).

Model1: $\Delta f k e_{t}=\alpha_{1}+\sum_{i=1}^{m} \theta_{i} \Delta f k e_{t-i}+\sum_{i=1}^{m} \emptyset_{i} \Delta f g e_{t-i}+\psi \mathrm{ECM}_{t-1}+\epsilon_{1 t}$

Model2: $\Delta f g e_{t}=\alpha_{2}+\sum_{i=1}^{m} \emptyset_{i} \Delta f g e_{t-i}+\sum_{i=1}^{m} \theta_{i} \Delta f k e_{t-i}+\psi \mathrm{ECM}_{t-1}+\epsilon_{2 t}$ 
Burada $\mathrm{ECM}_{\mathrm{t}-1}$ ile gösterilen değişken hata düzeltme terimidir ve değişkenler arasındaki uzun dönem ilişkilerin tahmin edildiği model kalıntılarının bir gecikmeli değerini ifade etmektedir. Hata düzeltme katsayısı ( $\psi)$, kısa dönemde değişkenler arasında ortaya çıkan bir dengesizliğin uzun dönemde ne kadarının giderileceğini göstermektedir. Hata düzeltme mekanizmasının çalışması için bu katsayının negatif işarete sahip olması ve istatistiksel olarak anlamlı olması gerekmektedir.

Değişkenler arasındaki kısa dönem ilişsileri araştırmak için oluşturulan ARDL Hata Düzeltme Modeli tahmin sonuçlarına göre (Tablo 9) hata düzeltme katsayısı (ECM(-1)), hem Model I (-0.174864) hem de Model II (-0.170604) için negatif işaretli ve istatistiksel olarak anlamlıdır. Her iki hata düzeltme katsayısının yaklaşık 0.17 olması kısa dönemde ortaya çıkan bir şokun \%17'sinin bir dönem içinde giderileceğini ve yeniden uzun dönem denge düzeyine dönüleceğini ifade etmektedir.

Tablo 9. ARDL Hata Düzeltme Modeli Tahmin Sonuçları

\begin{tabular}{|l|r|r|r|r|}
\hline \multicolumn{5}{|c|}{ Model I } \\
\hline Değişkenler & \multicolumn{1}{|c|}{ Katsayı } & \multicolumn{1}{|c|}{ Standart Hata } & \multicolumn{1}{l|}{ t-istatistik } & \multicolumn{1}{c|}{ Olasılık } \\
\hline$\Delta$ (fge) & 0.177774 & 0.073449 & 2.420360 & 0.0198 \\
\hline$\Delta$ (fge(-1)) & 0.186102 & 0.079787 & 2.332476 & 0.0244 \\
\hline ECM(-1) & -0.174864 & 0.038630 & -4.526597 & 0.0000 \\
\hline \multicolumn{5}{|c|}{ Model II } \\
\hline Değişkenler & Katsayı & Standart Hata & t-istatistik & Olasılık \\
\hline$\Delta$ (fke) & 0.523087 & 0.213290 & 2.452466 & 0.0184 \\
\hline$\Delta$ (fke(-1)) & 0.369155 & 0.239233 & 1.543077 & 0.1303 \\
\hline ECM(-1) & -0.170604 & 0.041509 & -4.110081 & 0.0002 \\
\hline
\end{tabular}

Not: *: \%1 anlamlılık düzeyini göstermektedir.

\section{Sonuç}

1980'lerin sonlarından itibaren gelişmekte olan ekonomiler, finansal serbestleştirmenin nimetlerinden yararlanabilecekleri düşüncesiyle finansal liberalleşme politikalarını hızlandırmışlardır. Uygun kurumsal ortama sahip olmadıkları için bu ülkelerin çoğunda finansal liberalleşmenin finansal gelişmeyi teşvik edemediği, ampirik çalışmalar tarafından da desteklenmektedir. $\mathrm{Bu}$ çalışmaların en önemli sonucu ise başarılı bir finansal liberalleşme politikası için kurumsal altyapının tamamlanmış olmasıdır.

Türkiye'nin de 1980 sonrasında başlayıp 1989'da tam geçiş yaptığı finansal liberalizasyon sürecinde bir taraftan finansal gelişimini sağlarken diğer taraftan finansal kırılganlıklara maruz kaldığı ve hatta krizler yaşadığı bilinmektedir. Ancak bu krizlerden çıkarılan dersler, zaman içinde finansal kırılganlıkların azaltılmasına yönelik birtakım yasal ve kurumsal 
düzenlemelerin yapılmasını da teşvik etmiştir. Türkiye zaman içinde olgunlaşan ekonomilerden biri olarak 2008 krizinden diğer krizlere kıyasla daha az zararla çıkmayı başarmıştır.

2007Q1-2019Q2 döneminin analiz edildiği çalışmadan elde edilen bulgular da küresel kriz sonrası dönemde Türkiye'de finansal gelişme sürecinin hızlandığını ve buna karşılık finansal kırılganlık düzeyinin ise dalgalanmalarla birlikte giderek azaldığını göstermektedir. Finansal gelişmişlik ile finansal kırılganlık arasında gerçekleşen ters ve çift yönlü ilişki, Türkiye'nin özellikle 2001 krizinden sonra finansal yapısını güçlendirmeye yönelik tedbirler açısından katettiği mesafenin önemini vurgular niteliktedir. Finansal gelişme düzeyinde meydana gelen bir artış karşısında finansal kırılganlık düzeyinin azalıyor olmasının nedeninin büyük ölçüde finansal aracılık faaliyetlerinin gelişimine ve bankacılık sektörünün fonlama düzeyine bağl1 olduğu söylenebilir. Gerçekleştirilen yasal ve kurumsal düzenlemeler sermaye hareketliliğine bağlı olarak artan spekülatif faaliyetler karşısında finansal kırılganlığın artmasını engellemektedir. Finansal istikrarın zarar görmesinin engellenmesi Türkiye'de finansal gelişmenin ekonomik büyümeye olan katkısını da güçlendirecektir.

Finansal kırılganlığın artmasının finansal gelişmeyi negatif yönde etkiliyor olması ise iç ve dış şokların finansal gelişme üzerinde etkili olacağını göstermesi açısından önemlidir. Bu durum, Türkiye'de finansal istikrardan ödün vermeyen ekonomi politikalarının gerekliliğine ve sürdürülebilirliğine vurgu yapacak niteliktedir.

Finansal kırılganlık ve finansal gelişme arasındaki ilişkilere yönelik çalışmaların yoğunlaşması Türkiye'nin finansal sistem altyapısının ihtiyaç duyacağı düzenlemelerin zamanında gerçekleştirilmesi açısından politika yapıcılara yol gösterici nitelikte olacaktır. Kurumsal düzenlemelerin finansal sistemin gelişmesine sağlayacağı katkılar, özellikle fiyat istikrarından ödün verilmeden finansal istikrarın sağlanmasını ve dolayısıyla sürdürülebilir ekonomik büyümeyi de beraberin getirebilir. Bu çerçevede 2020 yılında başlayan ve hala etkileri sürmekte olan pandeminin finansal sistemde ortaya çıkardığı kırılganlıkların analizi, pandemi sonrasında finansal gelişme ve büyüme ilişkilerinin iyileştirilmesi ve sürdürülebilirliğine yönelik düzenlemeler konusunda belirleyici olabilecektir. Finansal sistemin pandemi sürecindeki direnç düzeyinin belirlenmesi, Türk finans sisteminin kurumsal altyapısının bir testi mahiyetinde olup gelecekteki çalışmanın konusunu oluşturmaktadır. 
Felek, Ş., Yayla, N., Çeviş, İ. / Journal of Yasar University, 2021, 16/63, 1164-1184

\section{KAYNAKÇA}

Ahumada, Antonio, C., and Carlos, Budnevich, L.(2002). Some Measure of Financial Fragility in The Chilean Banking System: An Early Warning Indicators Application. in Banking Financial Integration and International Crises. edited by Leonardo Hernandez and Klaus Schimdt-Hebbel, Santiago, Chile.

Akalın, Uğur S. (2006), Üç Dönem Üç Ekonomi, İstanbul:Önsöz Basım Yayıncılık.

Andersen, T. B., and F. Tarp. (2003). "Financial Liberalization, Financial Development and Economic Growth in LDCs.” Journal of International Development, 15 (2): 189-209.

Balino, Tomas, and V. Sundararajan, (1991), Banking Crises: Cases and Issues, Washington: International Monetary Fund.

Barışık, S. ve Demirel, B. (2014). Finansal Kırılganlık ve Türk Bankacılık Sektörü için 2002-2011 Dönemi Finansal Kirılganlık Endeksi, TISK Akademi, 118-136.

Boot, A. (2000). "Relationship Banking: What Do We Know?" Journal of Financial Intermediation, 9 (1): 7-25.

Chinn, M. D., and H. Ito. (2006). "What Matters for Financial Development? Capital Controls, Institutions, and Interactions." Journal of Development Economist, 81 (1):163-192.

Claessens, S., A. Demirgüç-Kunt, and H. Huizinga. (2001).“How Does Foreign Entry Affect Domestic Banking Markets?" Journal of Banking \& Finance, 25 (5): 891-911.

Demirguc-Kunt, A and E Detragiache (1997). The Determinants of Banking Crises-Evidence from Developing and Developed Countries. IMF Working Papers.

Demirguc-Kunt, Asli, and Enrica Degatriache, (1998), "The Determinants of Banking Crises in Developing and Developed Countries," International Monetary Fund Staff Papers, 45 (1): 81-109.

Demirgüç-Kunt, A., and E. Detragiache. (1998). Financial Liberalization and Financial Fragility. Washington, DC: International Monetary Fund.

Denizer, C. A., M. Dinc, and M. Tarimcilar. (2007). "Financial Liberalization and Banking Efficiency: Evidence from Turkey." Journal of Productivity Analysis, 27 (3): 177-195.

Diamond, D. W., and P. H. Dybvig. (1983). "Bank Runs, Deposit Insurance, and Liquidity.” Journal of Political Economy, 91 (3): 401-419.

Dunteman G.H. (1989). Principal Components Analysis, Quantitative Applications in the Social Sciences, Sage Publications, USA.

Ertuğrul, A.; Yeldan, E. (2003). On the Structural Weaknesses of the post-1999 Turkish Disinflation Program. Turkish Studies, 4(2):53-66

Gavin ve Hausmann, 1995). Gavin, Michael, and Ricardo Hausmann, (1998). "The Roots of Banking Crises: The Macroeconomic Context," in Banking Crises in Latin America, Ricardo Hausmann and Liliana RojasSuarez, editors, Washington: Interamerican Development Bank.

Gore, C. (2000). "The Rise and Fall of the Washington Consensus as a Paradigm for Developing Countries." World Development, 28 (5): 789-804.

Hawkins, J.; Klau, M. (2000). Measuring Potential Vulnerabilities in Emerging Market Economies. BIS Working Papers, 91.

Hellmann, T. F., K. C. Murdock, and J. E. Stiglitz. (2000). "Liberalization, Moral Hazard in Banking, and Prudential Regulation: Are Capital Requirements Enough?” American Economic Review, 90 (1): 147165.

Hermes, N., and A. Meesters. (2015). "Financial Liberalization, Financial Regulation and Bank Efficiency: A Multi-Country Analysis." Applied Economics, 47 (21): 2154-2172

Jung, W. S. (1986). Financial Development and Economic Growth: International Evidence. Economic Development and Cultural Change, 34(2): 333-346.

Kaminsky, G. L., and S. L. Schmukler. (2008). "Short-Run Pain, Long-Run Gain: Financial Liberalization and Stock Market Cycles.” Review of Finance, 12 (2): 253-292.

Khan, M. A. ; Qayyum, A. ; Shikh, S. A. (2005). Financial Development and Economic Growth: The Case of Pakistan [with Comments], The Pakistan Development Review, pp.819-837.

Klein, M. W., and G. P. Olivei. (2008). "Capital Account Liberalization, Financial Depth, and Economic Growth." Journal of International Money and Finance, 27(6): 861-875.

Lynch, D. (1996). Measuring Financial Sector Development: A Study of Selected Asia-Pacific Countries. The Developing Economies, 34(1): 1-27.

McKinnon, R. I. (1973). Money and Capital in Economic Development. Washington, DC: Brookings Institution.

OECD (2005). Handbook on Constructing Composite Indicators: Methodology and User Guide, OECD Statistic Working Papers, OECD Publishing, 2-108. http://dx.doi.org/10.1787/533411815016.

Pesaran, M.H., Shin, Y. and Smith, R.J., (2001). Bounds Testing Approaches to the Analysis of Level Relationships, Journal of Applied Econometrics, 16:.289-326.

Robinson, J. (1952). The Generalization of the General Theory and Other Essays, London: MacMillan.

Rodrik, D. (1998). "Who Needs Capital-Account Convertibility?" In Should the IMF Pursue Capital-Account Convertibility? Essays in International Finance, No. 207, International Finance Section, edited by 
S.Fischer, R. N. Cooper, R. Dornbusch, P. M. Garber, C.Massad, J. J. Polak, D. Rodrik, and S. S. Tarapore, 55-65. Princeton: Princeton University.

Rossi, M. (1999). Financial Fragility and Economic Performance in Developing Economies-Do Capital Controls, Prudential Regulation and Supervision Matter?. International Monetary Fund Working Paper, WP/99/66.

Roubini, Nouriel, and Xavier Sala-i-Martin, (1992). "Financial Repression and Economic Growth," Journal of Development Economics, 39 (1): 5-30.

Sahay, M. R., M. Cihak, M. P. N’Diaye, M. A. Barajas, M. D.A. Pena, R. Bi, Y. Gao, et al. (2015). "Rethinking Financial Deepening: Stability and Growth in Emerging Markets." IMF Staff Discussion Note No. 1518. Washington, DC: International Monetary Fund.

Schumpeter, J. (1911). The Theory of Economic Development: An Inquiry Into Profits, Capital, Credit, Interest and The Business Cycle. 1934 translation. Cambridge, Mass: Harvard University Press.

Shaw, E. S. (1973). Financial Deepening in Economic Development. New York: Oxford University Press.

Stiglitz, J. E. (2000). “Capital Market Liberalization, Economic Growth, and Instability.” World Development, 28 (6): 1075-1086.

Varlık, N. (2016), Türkiye'de Finansal Gelişme ile Finansal Kırılganlık İlişkisi, 1990-2014 Dönemi, Ekonomik Yaklaşım Derneği (EYD), 27(98), ss:141-176.

Von Furstenberg, George M.; Fratianni, Michele (1996). Indicators of Financial Development. The North American Journal of Economics and Finance, 7(1): 19-29.

Yıkmaz R.F. (2011). Sürdürülebilir Kalkınmanın Ölçülmesi ve Türkiye İçin Yöntem Geliştirilmesi, Uzmanlık Tezi, Devlet Planlama Teşkilatı (DPT)Sosyal Sektörler ve Koordinasyonlar Genel Müdürlüğü, Yayın No:2820, Ankara. 